\title{
The Dispute Settlement Model of Regional Head Election Perspective Theory of Legal System in Indonesia
}

\author{
Dedi Mulyadi ${ }^{*}$ \\ Tanti Kirana Utami ${ }^{1}$ \\ ${ }^{1}$ Faculty of Law, Suryakancana University, Cianjur, West Jawa, Indonesia. \\ *Corresponding Author, Email: dedimulyadi53@gmail.com
}

\begin{abstract}
:
The effectiveness of law enforcement depends on three law aspects; those are the structure of law, the substance of the law, and legal culture. Law structure is about the law enforcers, law substance is about the legislative means, and law culture is about a living law adopted by society. This study defines the background of simultaneous regional head elections in Indonesia, the problems of the simultaneous regional head elections in Indonesia, and the implementation of legal system theory to solve the simultaneous regional head election problems in Indonesia. The research method used is normative juridical with the specification of descriptive analysis research. The result of the research is needed permanent law structures that cover (Election Police, Election Prosecutor, Election lawyer, and Election Jury), the law substance through the issuing of general regulations (lex general) which can integrate the Laws of Legislative, Presidential, and Regional Head Elections (lex specialist) and the legal culture of society as human behavior (including the legal culture of law enforcement officers) on the electoral law and law system that are in force at the moment.
\end{abstract}

Keywords: Democracy, Regional democracy, Regional head elections, Law structure, Law substance, Law culture.

\section{A. INTRODUCTION}

Internalizing values of sovereignty (sovereigniteit) is an application of the law enforcement characters of democracy, sovereignty has a very long story, in the sense that sovereignty is theoretically older from the concept of the state itself (Pantja and Na'a, 2009: 108). It is in accordance with James Bryce statement that said dusty desert of abstraction through which succesive generation of political philosophers have though it necessary to lead their disciples (Isjwara, 1980: 105). Meanwhile, Jean Bodin said that the supreme authority to create law in a country should have the following characters:

1. Singular, it means that it is only the state who has the power. There is no other power than the country that has the right to determine or make the regulation or law;

2. Original, it means that the power did not come from any other power, not inherited or given by another authority. For example, the one that come from the province or municipality that do not have sovereignty, because the power they have are not original, because they get it from the central government;

3. Eternal, it means that it is the state who has the highest power or sovereignty, which according to Jean Bodin the state is eternal; 
4. Can not be divided, it means that sovereignty can not be handed over to another person or entity, either partially or wholly.

The term people sovereignty or democracy is etymologically derived from the Greek "demos" which means "people" and the word "kratos" or "cratein" which means "government". Based on the definition, the word "democracy" has a meaning as "government by the people" or "people's sovereignty". Abraham Lincoln, stated the term "government of the people, by the people, and for the people". The term has a meaning that power is in the hands of the people, M. Duverger in the book 'les regimes Politiques' defines the meaning of democracy as a way of government to rule together the ruling class and the ruled class equally and are not separately (Budiarjdo, 1997: 54). One of the basic requirements to be a democratic country is that the country should have an election system that are free and fair (free and fair elections).

Indonesia as a democratic constitutional state is a manifestation of democratic values of Indonesian legal political state today and in the future, in line with the substance of the 1945 Constitution, Article 1 paragraph (2) which states that "Sovereignty belongs to the people and carried out by the 1945 Constitution". The implementation of Paragraph (2), especially in the term of fulfilling political position in the regions is carried out through a model election of direct Regional Head/Deputy Regional Head elections and as regulated in the amendment of the 1945 Constitution, Article 18 paragraph (4) which states that 'Governors, Regents, and Mayors that are respectively as the head of the government in a province, region, and city are elected democratically'.

The phrase '....elected democratically' is then translated through the Law No. 1 Year 2015 about the Implementation of the Regulation in Lieu of Law No. 1 Year 2014 about the Elections of Governors, Regents and Mayors into a law. In the implementation of simultaneous electoral dynamics in Indonesia that rise various problems as an alternative solution in accordance with the Article 134 of the law, covering the Violation of Code of Ethics problem in the elections process is forwarded by Bawaslu to DKPP, the Violations of Election Administration is forwarded to the KPU, Provincial KPU, or KPU in Regency/City, the dispute arises in elections will be soved by Bawaslu, the crime in elections will be followed up by the Indonesia National Police, and the dispute arises because of the election results will be solved in the Constitutional Court to set up a special judicial bodies in accordance with Article 157 Paragraph (3) of Law No. 8 Year 2015 (Harun, 2016: 3).

Susan Hyde, et al, in her book entitled 'Election Fraud: Detecting and Deterring Electoral Manipulation', defines the main issues in the elections are to recognize and prevent the occurrence of the phenomenon of electoral fraud, election manipulation, or vote rigging an election fraud that occurred because of illegal intervention or interference against the administration of the election process (Gaffar, 2013: 77). This action affects the counting of votes in the elections that can affect the result of the election, either the one that increase the voting results, reduce the voting results, or both toward the specific candidates. Although, technically, the "electoral fraud" includes an illegal act that violates the law, but the legal action is morally unacceptable, does not reflect the spirit of the electoral rules, and in a contrary to the principles of democracy included in the category of "electoral fraud".

From the various problems that occur in elections, the enforcement of the election law in accordance with the electoral law to fulfill the aspiration and expectations of the society, the implementation was influenced by various theories such as the theory of 'legal system' that conveyed by Lawrence M. Friedman as effective and the success or failure of the law enforcement depends on three elements of the legal system, namely: the legal structure (structure of law) that concerns on the law enforcement officials, legal substance (substance of law) includes means in the implementation of 
electoral law and the legal culture (legal culture) is living law that is adopted in a society that conducts the elections.

This series of stories are initial information in internalizing the 'dispute settlement model of regional head election perspective theory of legal system in Indonesia'. Based on the background of the study above, we carry out the identification of the problems, namely:

1. What is the background of the conduction of the simultaneous elections in Indonesia?

2. What are the problems of the simultaneous elections in Indonesia?

3. Could the implementation of the legal system theory settle various problems of the simultaneous elections in Indonesia?

\section{B. METHODS}

According to the problems mentioned above, the researcher carried out a normative legal research that used secondary data that is derived from library materials (Soekanto, 2008: 11). The data collection method was through the study of literature by examining and exploring legal materials or written data in the form of books of law, court decisions, books, journals, magazines, newspapers, web, and other legal materials that are related to the issue, so this study can be called as a research literature, the study of secondary materials (Soekanto, 1985: 15).

\section{RESULTS AND DISCUSSIONS}

\section{The Background of The Implementation of Simultaneous Elections in Indonesia}

Election in Indonesia is one of the means of democracy (Nugroho, 2016: 482). The democracy party embodies the order of statehood that has sovereignty of the people, government from and for the people (Marpaung, 2013: 381). The implementation of election can be explained into threedimensional achievements as follows:

a. Through elections, we can find out our political rights through a simultaneous and massive scale;

b. Through elections, we can expect the process of the political recruitment in a fair, open, and competitive way;

c. Through elections, we may have a peaceful succession of power.

Thus, election is an integral part of a democratic system that is developing in Indonesia in the mean time, particularly the one that held the implementation of local democracy. A new round in the implementation of local democracy in Indonesia started in June 2005. The Regional Head (governors, regents, and mayors) were previously selected through an election mechanism by the Parliament (DPRD) in accordance with Law No. 5 Year 1974, Law No. 22 Year 1999 about Regional Government that the results do not reflect the values of democracy system, even the political horsetrading trends (bargaining) which resulted a mistrust (distras) from the public on the results of the representative democratic process.

Under these conditions, since June 2005 the local elections are conducted through the mechanism chosen directly by the people through a process of direct local elections, in accordance with Law No. 32 Year 2014 about the Regional Government, then halted in 2015 in accordance with Law No. 8 Year 2015 the Phase I simultaneous local elections has held and on 2017 the Phase II simultaneous elections has held implemented. The important meanings of the elections 
implementation are 1) a constitutional recognition of the rights of the people to have sovereignty; 2) the people's substantial role become a political institutionalization as a legal subject; 3) the expectation of the occurance of micro and macro political balance in our civic life, especially between the executive and the legislative aspects (Saputra, 2010: 95).

Historically, the background of the political choice towards the direct regional elections system is a correction for the electoral implementation in the past. The implementation of direct elections system shows the development of the democratic system arrangement within the framework of the political area transition. Of course, the direct simultaneous electoral system causes varied expectations of new local democracy. In the global developments, the backgrounds of local direct elections of the heads of regions in the development of local democracy in Indonesia, are explained as follows:

a. Direct election is a response to the urge of the implementation of democratic system in Indonesia from the international community, especially local democracy;

b. Direct election is a in response to the aspirations and expectations of the people about the Presidential, the House of Representatives, even the Village Chief elections that are carried out directly;

c. The direct regional election is a development from constitutional local democration in accordance with the mandate of the 1945 Constitution, Article 18 Paragraph (4), governors, regents and mayor, respectively as the head of the provincial, district, and city elected democratically, then interpreted through Law No. 102016 Second Amendment to Law No. 12015 On Establishment Regulation in Lieu of Law No. 12014 On the Election of Governors, Regents and Mayors into law;

d. Direct regional elections as a learning mean for local democracy (civic education), it is as a means of democracy education for the people, who previously only know elitist democracy;

e. direct elections as a means of strengthening local autonomy with the motto 'problems of the region, settled in the area by way of the area, the local community';

f. Direct elections as a strategic mean in the regeneration process of national leadership, one of the products in the form of the regeneration of the leader is President Joko Widodo (Mudiarti Trisnaningsih, 2012: 1347).

Thus the direct elections are considered as the embodiment of returning people's fundamental rights in the region by providing a complete authority in the framework of regional head election through local democratic legitimacy as the purpose of elections (Wijayanti, 2010: 94). The success of an election to create a local democratically and legitimately leadership, according to the will and demands of the people a lot, it really depends on the local community's own articulation of democracy in interpreting the development and dynamics of the democratic expectations.

\section{Issues in Indonesian Simultaneous Regional Head Election Implementation}

The 1945 Constitution of the Republic of Indonesia, Article 18 Paragraph (4) states that "Governors, Regents, and Mayors as the respective heads of government of the provinces, regencies, and cities chosen democratically". The article, as the basis for the implementation of elections as a means of implementation of the people's sovereignty in the respective provinces, districts and cities based on Pancasila and the 1945 Constitution to elect regional heads and deputy regional head (Saputra, 2010: 94). 
Nowadays, the local democracy in Indonesia is implemented through local elections that cause the occurance of some problems, political implications, and socio-economic impacts, either favorable or unfavorable. Many opinions appeared give criticize about the elections, but there is also a discourse that give explanation and appreciation of the elections as an effort to create a responsive government with a social-political implications.

Furthermore, the problems in the implementation of direct regional elections of Heads of Regions is in accordance with Law No. 10 Year 2016 a second amendment of Law No. 1 Year 2015 about the Establishment Regulation in Lieu of Law No. 1 Year 2014 about the Election of Governors, Regents, and Mayors as a Law:

a. Money politics, taking advantage from the economic inability of the public in general, makes money politics into one of the fastest effort to get the people's voices;

b. Intimidation, intimidation is often done to the voters, especially in areas that have historical conflicts such as Aceh, etc;

c. Negative campaign, negative campaign is done because people do not get enough information about the candidates so this situation is used by certain groups to blow up the negative information in social, printed, and electronic media;

$d$. The entire stock of the party for a single candidate, the latest information in accordance with the decision of the Constitutional Court (Mahkamah Konstitusi/MK) to allow a single candidate in the implementation of direct elections provide chances for the candidate who has capital strength to invite political parties participating in the election, so that the other candidates will not get the bearer parties and independent candidates are very difficult to participate in the elections.

e. Sara issues (ethnicity, race, and religion), the phenomenon to use Sara issues as part of an election can be seen in the election of the Governor of Jakarta, where the candidate No. 2 (Ahok and Djarot) are in the middle of legislative process because the offense of blasphemy, which is still in ongoing process.

Based on the data from the Ministry of Domestic Affair, since the implementation of the simultaneous direct elections that began in 2005, there were 25 (twenty-five) crime that killed 59 (fifty nine) people, and 230 (two hundred thirty) other hurt. This unrest has damaged 279 (two hundred and seventynine) houses, 30 (thirty) local government offices, and 10 Regional Election Commission Office (Supryanto, 2013: 1-2).

Furthermore, the Commission (KPU) in a hearing meeting with the Commission II of the House of Representatives (DPR-RI) in Jakarta stated that in the elections held in 2015 there were 12 (twelve) problems occured: 1) the findings of false documents in eight (8) regions; 2) two lisme of management in 18 (eighteen) areas; 3 ) the requirements of supporting parties occurred in 16 (sixteen) areas; 4) the problems in the registration stage; 5 ) the compliance documents from other agencies; 6 ) requirements for former inmates who are advanced in the elections; 7) The problem of the status of the re-developed incumbent in the election; 8) the problem of support for individual candidates; 9) problems related to the health condition; 10) changes information in the application document from the candidates; 11) problems suspect the candidates' status; 12) candidates replacement that are not in accordance with the provisions. The Commission (KPU) findings can then be grouped on the problems rose because of falsification of documents, political parties' conflicts, the election administration as well as the appropriateness and propriety of the candidates, for example regarding the suspect status of the candidates. 
Ekatjahjana (2010: 114), stated that fundamental problems in handling violations and disputes elections as mentioned above, are still processed by three judicial institutions (violation determination Election by the Administrative Court (PTUN), violations of the Criminal Election by $\mathrm{PN}$, and disputes by the Court (MK)), the question is why there should be three legal institutions of justice handle the legal election disputes in Indonesia. Those are the description of various issues that will be and are rising in the mean time; they are part of the risk of the policy implementation about Election of Head of Regions as the dynamics of the implementation of local democracy in Indonesia.

\section{The Implementation of the Legal Theory Could Be the Settlement of Various Problems in the Implementation of Simultaneous Direct Elections in Indonesia}

Regulatory issues on holding local elections in Indonesia state system is actually very complex and complicated, the people still have partial understanding and perception about the implementation system and the rule of the elections, the establishment of regulations and legal culture of law enforcement and the community will not only affect the quality or legitimacy and results of the elections hold, it also has implications for the quality of democracy and the possibility of potential political instability of the state (Ekatjahjana, 2010: 109-110).

In the settlement of various potential problems above, an expert in law sociology from Stanford University, Lawrence Meir Friedman, has a thought that the success or failure of law enforcement, especially in local elections depends heavily on three main elements of the legal system, namely: 1) Legal Structure; 2) Legal Substance; 3) Legal Culture. Organization factors (legal structure) of elections have a very significant influence on the quality of the result of the elections themselves, the structural systems that determine whether the law was implemented well or not. The structure of the election law was based on Law No. 8 Year 2015 include the Police, Judiciary, Supervisory Committee, the Commission, Gakumdu, Courts, Lawyers, and Prisons that have been ad-hoc, that in the future it is expected become permanent with competemce human resources to conduct elections from various perspectives in accordance with their needs.

The authority of the election law enforcement agencies are guaranteed by law. Thus, in carrying out their duties and responsibilities they are not under the influence of the powers or government and other influencers. This is in line with the adage that says "fiat justitia et pereat mundus", though the world is crumbling the justice must be carried out. Justice can not be implemented or done when there is no credible, acceptable, competent, and independent law enforcement officers in the settling various problems in elections.

Furthermore, the substance of law in elections determines whether the law will be implemented or not. Substance means the products resulting from the judiciary institution are in accordance with the rules they regulated. Substance also includes the living law, not only the existing rules in the book of the law (law books). The substance of the regulation of election law at the moment consists of the 1945 Constitution, Article 18 Paragraph (4) as a constitutional basis and operation foundation in particular (lex specialist) is regulated by Law No. 10 Year 2016 as the second amendment to Law No. 1 Year 2015 about the Establishment Regulation in Lieu of Law No. 1 Year 2014 about the Election of Governors, Regents, and Mayors become a law, Law No. 15 Year 2011 concerning on the Election Organizers defines by the Commission Regulation, Bawaslu Regulation, Court Regulation and so forth. 
In the future, regulations that can integrate the various specific regulations to common rules are needed through the Electoral Law (lex generalis) in accordance with the legal hierarchy (The Hierarchy of Law) based on the thoughts of Hans Kelsen, so that the Electoral Law which is lex generalis become the answer to regulation that is needed in settling various problems continuously in General Election/Election of Head of Regions (Muda and Kadafi, 2013: 18).

In settling various problems above, the legal culture factor of society becomes very important and strategic where legal culture in general can be interpreted as a human attitude toward law and the legal system, beliefs, values, thoughts, and hopes. Legal culture is an atmosphere of social thought and social forces that determine how the law is used, avoided, or misused. Legal culture of society in delivering and accepting the election results is closely associated with the law awareness rate of the society. The higher the law awareness of the society of the importance of the elections in the democratic process the better legal culture they get that can lead to the better understanding of the society in regarding the law during elections especially their perception in choosing the heads of regions. Simply, the level of public compliance on the implementation and the results of the elections is one indicator of the effectiveness of the general law in Indonesia.

\section{CONCLUSION}

The phenomenon of simultaneous local elections is a means of people's sovereignty as one of the characteristics of the countries that apply the system of local democracy in local governance processes. Therefore, the researcher derived the following conclusions:

The background of the implementation of elections that are held simultaneously in Indonesia, historical background of the enactment of Law No. 22 Year 1999 about the Regional Government, the policy of local democracy in Indonesia through the elections of governors, regents, and mayors who are previously elected indirectly, through the mechanism of the elections set by the parliament (DPRD) that the results are considered undemocratic by the tendency of horse-trading politic (bargaining) that lead to distrust from the public toward the process. As a consequence, the government implemented a policy in holding direct democracy through local elections to choose the heads of regions as in accordance with Law No. 32 Year 2004 about the Regional Government that is amended by Law No. 23 Year 2014 about the Regional Government. Before 2005, direct elections were held not in a simultaneous way resulting various exses that can disrupt the transition of local democracy process in Indonesia in the mean time. Based on current economic conditions, the government carried out the evaluation of the direct elections and determine the policy of Simultaneous Direct Election in 2 (two) phases that in 2005 Phase I of the Simultaneous Direct Election has held and Phase II has held in 2017.

The problems in deciding political positions through simultaneous elections as described in the foregoing discussion is in line with the 1945 Constitution, Article 18 Paragraph (4) which states that "Governors, Regents, and Mayors as the respective heads of government of the provinces, districts, and cities respectively in a democratic manner". This article contains the regulation to decide the position of regional head, select the regional head and the deputy of regional head simultaneously in a theoretical context of local democracy is closely related to the decentralization of power. The decentralization of power is basically implemented based on the autonomy at the local level to manage the household. While political recruitment is the process of deciding political position in a country in order to enable well political system to provide services and protection to the public. 
Various attempts of settling elections problems in deciding political positions in Indonesia can generally be categorized into three (3) major categories, such as problems that can be settled through the issuance of regulations, infrastructure, and sustainable electoral education. These three efforts are expected to be alternative solution to the implementation of simultaneous local elections on an ongoing basis. 


\section{References}

Astawa, I. Gede Pantja., Na'a, Suprin. (2009). Memahami Ilmu Negara \& Teori Negara. Bandung: Refika Aditama.

Budiarjo, Miriam. (1997). Dasar-Dasar Ilmu Politik. Jakarta: Gramedia Pustaka Utama.

Ekatjahjana, Widodo. (2010). "Beberapa Masalah dalam Pengaturan dan Penyelenggaraan Pemilu/ Pemilukada di Indonesia". Jurnal Konstitusi PK2P-FH Universitas Muhammadiyah Yogyakarta. III (1). Jakarta: Mahkamah Konstitusi.

Gaffar, Janedjri M. (2013). Politik Hukum Pemilu. Jakarta: Konstitusi Pers.

Harun, Refly. (2016). "Rekonstruksi Kewenangan Penyelesaian Perselisihan Hasil Pemilihan Umum". Jurnal Konstitusi. 13 (1). Jakarta: Mahkamah Konstitusi.

Isjwara, F. (1980). Ilmu Politik. Bandung: Bina Cipta.

Marpaung, Satrya Pangadaran. (2013). "Strategi Hukum dan Demokrasi di Indonesia dalam Pelaksanaan Otonomi Daerah". Law Review. XII (3). Jakarta, Fakultas Hukum Universitas Pelita Harapan.

Muda, Iskandar., Kadafi, Muhammad. (2013). "Penerapan Konsep Hukum Pembangunan Ekonomi dalam upaya pencegahan eksploitasi pekerja alih daya Kajian Putusan Mahkamah Konstitusi Nomor 27/PPU-IX/2011". Jurnal Yudisial. 6 (1). Jakarta: Komisi Yudisial.

Nugroho, Wahyu. (2016). "Politik Hukum Pasca Putusan Mahkamah Konstitusi atas Pelaksanaan Pemilu dan Pemilukada di Indonesia". Jurnal Konstitusi. 13 (3). Jakarta: Mahkamah Konstitusi.

Saputa, Andi. (2010). "Faktor-faktor Kemenangan Calon Incumbent dalam Pilkada", in Jurnal Konstitusi. PK2P Universitas Muhammadiyah Yogyakarta. III (1): 70-82.

Soehino. (2000). IImu Negara. Yogyakarta: Liberty.

Soekanto, Soerjono. (1985). Penelitian Hukum Normatif suatu tinjuan singkat. Jakarta: Raja Grafindo.

Soekanto, Soerjono. (2008). Pengantar Penelitian Hukum. Jakarta: UI Press.

Supryanto, Didik. (2013). Pilkada Serentak Menuju Pemilu Serentak, disampaikan dalam Diskusi Publik Mencegah Politik Biaya Tinggi dalam Pilkada yang diselenggarakan Perludem di Hotel Akmani Jakarta.

Trisnaningsih, Mudiarti. (2012). "Peranan Hukum di Era Globalisasi", in Jurnal IImiah Hukum Litigasi. Vol. 1 (1), Fakultas Hukum Universitas Pasundan, Bandung.

Wijayanti, Septi Nur. (2010). "Pergeseran Kewenangan Penyelesaian Sengketa Pemilukada dari Mahkamah Agung ke Mahkamah Konstitusi". Jurnal Konstitusi. III (1). Jakarta: Mahkamah Konstitusi. 
The Dispute Settlement Model of Regional Head Election

Perspective Theory of Legal System in Indonesia 